\title{
Biracialism and trauma in Kaine Agary's Yellow-Yellow
}

Kayode Omoniyi Ogunfolabi

\section{Biracialism and trauma in Kaine Agary's Yellow-Yellow}

The connection between the discourse of racial purity and its traumatic effects on the biracial woman takes center stage in Kaine Agary's Yellow-Yellow, which manifests in valorization and vilification of biracial subjects. Contrary to received and discriminatory knowledge that equated biraciality with degeneracy and hyper-sexuality, this article argues that master narratives of social marginality, and stigmatization of biracial women are undermined through the counter-narrative of subjects that deconstructs the dialectic of visibility and invisibility of the biracial body. Appropriating the stereotypes against them, victims recover their subjectivity by articulating their stories, which transgress an ossified binary perception of race. Though these stories do not provide narrative closure, they embrace the contradictions and ambivalence that characterize existential realities of biracial bodies, and therefore, rupture the singular and normative narrative that names biracial women as 'other'. Keywords: biracialism, trauma, visibility, invisibility, testimony.

\section{Introduction}

The story of the biracial woman in Kaine Agary's Yellow-Yellow is inscribed indelibly on her body. ${ }^{1}$ It is this story that precedes her entry into the narrative of Nigerian ecopolitics; in other words, the story that the biracial body is capable of telling reveals the operation of power in the production of socially sanctioned ordering of bodies. Yellow-Yellow contains multiple narratives, one of which is that of repressive dictatorship, which in Nigerian history corresponds to Sani Abacha's infamous regime that executed the writer and environmental activist, Ken Saro Wiwa. Apart from this, Agary's novel presents the struggle of Niger-Delta militants who fight the recklessness and exploitation of the oil companies, and particularly, raises awareness about the negative impact of oil drilling on the social, economic, and political lives of the people of the Niger-Delta. Another important story is that of young girls who migrate to urban centers with the dream of social mobility either through romance with expatriates or prostitution involving a broad range of clients.

Yet within these competing stories is that of the group of female children referred to simply as, "Yellow-Yellow" or "Yellows". The novel focuses exclusively on the women, making it difficult to assess the experience of biracial men. But the fact that the subjects in Yellow-Yellow are women shows that their plight is relatively gender-based. Precisely because the experience of these biracial women is intensely personal, it slides under dominant narratives. However, through the narrator-protagonist-Zilayefa-Agary's novel shows that social exclusion of biracial women is not necessarily anchored on white ancestry but is rather legitimized by indirect evocation and valorization of racial authenticity, according to which 'white' and 'black' become uncontaminated and unproblematic racial categories.

On the one hand, society inscribes the biracial body with exotic visibility while, on the other, forces it to social invisibility. In other words, by transgressing black and white, the biracial woman unsettles the normative categories of race and consequently becomes 'the other'. This 'otherness' constitutes the major cause of pain for the biracial characters of Kaine Agary's Yellow-Yellow. As the discussion of the text will show, this dialectic of visibility and invisibility produces traumatic experience in the protagonist. In articulating this experience of trauma, the novel rewrites the master narratives of racial exclusivity. By privileging the voices of biracial women, Yellow-Yellow appropriates and distorts the narrative of racial chauvinism.

Many critical responses to Kaine Agary's Yellow-Yellow have addressed the exploitative practices of the oil multinationals, degradation of the environment, violence, impoverishment of the people of Niger-Delta, and the

Kayode Omoniyi Ogunfolabi is a senior lecturer in the department of English, Obafemi Awolowo University, lle-Ife, Nigeria. Some of his research interests are trauma, Nigerian women's fiction, and postcolonial magical/marvelous realist fiction.

Email: kayodeogunfolabi@gmail.com

(iD https://orcid.org/0000-0001-8419-5631

DOl: dx.doi.org/10.17159/2309-9070/tvl.v.56i2.4664 
predicament of biracial children, especially women. For example, both E. D. Simon and Michael Janis have noted the protagonist's vulnerability to sexual predation (Simon 163; Janis 326).

Charles Cliff Feghabo claims that there are different levels of "otherness" in the novel and that the Ijaw women are the ones that suffer the most because they are oppressed by the state and the patriarchal system. It is for this reason that he refers to the women as triple subaltern (317). In addition, he addresses what he calls the "enormity of the psychological trauma she [Zilayefa] and her like that abound in the Delta have to contend with" (321), which in a way signals the traumatic dimension of being biracial in the Niger-Delta region. Ignatius Chukwumah also claims that the network of oppressive institutions constitutes what he calls the "displaced male image", through which the protagonist's suffering assumes a gendered identity—male (49). Solomon Azumurana contends that the women in Agary's novel appropriate the positions of absent relations as a means of survival (151). While these perspectives on Agary's novel illuminate one's understanding of the text, they also make it possible to discover other aspects of the novel that are germane to analyzing the plight of the biracial woman but which are yet to be explored.

Although Simon, Janis, Chukwumah, and Azumurana have addressed the connection between the excesses of the oil companies in the Niger-Delta, sexual exploitation of Ijaw women, the representation of oppressive state and social institutions as male, and the impact of absent family members on some of the characters in the novel, they seem to have based their claims on the broader issue of family, state, and multinational exploitation of oil resources. While focusing on this systematic exploitation is important in and of itself, it omits the unique experience of the biracial woman, who is a victim in more ways than one. For instance, social subordination of women, economic challenges, sexual exploitation, and stigmatization of the yellow skin, all complicate the daily living of the biracial woman. Unlike Simon and Janis, Feghabo refers to the particular circumstance of biracial women, which he describes as "psychological trauma." Despite Feghabo's reference to psychological trauma, he does not pay close attention to the ways in which the novel creates the narrative of 'otherness', and in particular, how the protagonist functions as a subject of trauma. In other words, by lumping the protagonist and other biracial women together, Feghabo homogenizes all biracial women, implying that their experiences are more or less the same. Agary's text, in fact, resists homogenization by showing that biracialism is over-determined by factors such as class, family backgrounds, and socialization. However, it is in the character of Zilayefa, the narrator-protagonist, that the trauma of racial preferences can be appreciated precisely because the story of Yellow-Yellow is rendered through her voice.

After an initial exploration of trauma theory as it relates to the novel, this essay will be in three parts: the first addresses the valorization of racial authenticity and simultaneous vilification of biracial identities. This reading will be done through an interpretation of one of the characters' (Madam George, aka Sisi) story. The second section uses Caruth's template of trauma to demonstrate the sense in which the protagonist is a victim of trauma. Finally, the article shows how the text thematizes narrative agency on the part of the protagonist as a necessary step towards undermining the metanarrative of racial purity and attenuating the traumatic effects of otherness.

\section{Trauma}

The term 'trauma' is used in this article, not in the broader and loose description of pain, but in the narrower sense, which consists in how a violent event in the past returns to haunt the survivor. Cathy Caruth asserts that trauma used to be understood as a wound inflicted on the body (3). However, the meaning of the term has undergone changes:

In its later usage the term trauma is understood as a wound inflicted not upon the body but upon the mind. But what seems to be suggested by Freud in Beyond the Pleasure Principle is that the wound of the mind - the breach in the mind's experience of time, self, and the world - is not, like the wound of the body, a simple and healable event, but rather an event that $[\ldots]$ is experienced too soon, too unexpectedly, to be fully known and is therefore not available to consciousness until it imposes itself again, repeatedly, in the nightmares and repetitive actions of the survivor [...] [S]o trauma is not locatable in the simple violent or original event in the individual's past, but rather in the way that its very unassimilated nature - the way it was precisely not known in the first instance - returns to haunt the survivor later on. (3-4; original emphasis)

For Caruth, what is important to know about trauma is not just the event, but the impact of the event on the mind of the survivor beyond the moment in which the event occurred. Trauma is therefore crucial for Caruth "not only 
because it depicts what we can know about traumatizing events, but also, and more profoundly, because it tells of what it is, in traumatic events, that is not precisely grasped" (6; original emphasis). The very thing that constitutes the traumatic is the persistent return of the lacuna in the event, which the survivor is unable to account for.

Discussing the connection between time and the unconscious Victor Burgin seems to corroborate this notion of trauma when he says that "the past event, whether actual or fictional, produces real effects in the present" (118), and affirms Freud's contention that "There is no time in the unconscious" (qtd in Burgin 118). Thus, trauma is contingent upon a traumatic memory's ability to transgress space and time mainly because of the epistemological void that it creates in the survivor: "trauma consists not only in having confronted death but in having survived, precisely, without knowing it" (64; original emphasis). That is, the survivor is haunted by the mystery of survival rather than the actual confrontation with death. It is this mystery that causes the survivor to relive the traumatic event without knowing that the past haunts them because of their inability to understand how they managed to escape such an encounter with death.

Closely related to Caruth's idea of trauma is Felman and Laub's argument that traumatic memory is usually submerged and, in the process of being submerged, gets distorted (76). Their argument suggests that the traumatic event resists full apprehension by the survivor but they suggest as well that the longer the story is withheld, the more distorted it becomes. For them, "[t]here are never enough words or the right words, there is never enough time or the right time, and never enough listening or the right listening to articulate the story that cannot be fully captured in thought, memory and speech" (78; original emphasis). They advocate telling one's story as a way of liberating oneself from the shackles of the traumatic past. They contend that:

$[\mathrm{T}]$ he 'not telling' of the story serves as a perpetuation of its tyranny. The events become more and more distorted in their silent retention and pervasively invade and contaminate the survivor's daily life. The longer the story remains untold, the more distorted it becomes in the survivor's conception of it, so much so that the survivor doubts the reality of the actual events. (79)

Precisely because the traumatic event is submerged and always already distorted, it is crucial that the survivor tells their story in order to escape its tyranny, which can be as traumatizing as the event.

However, Zoe Norridge argues that "[p]ain, then, in the body of works associated with trauma theory, is enduringly described through its absence" (6). She contends that inability to narrate one's story of pain or inaccessibility of one's story silences that story, in particular when this has to do with colonized societies (8). In her revision of trauma theory, Norridge says that trauma theory can be linked to the ascendancy of post-structuralism, which is skeptical of the reliability of any representational system. She emphasizes this point when she says: This concept of unrepresentable lacuna of testimony is based on three lines of thought: deconstruction, with its emphasis on the impossibility of ever fully representing what is sought to be represented in language; psychoanalysis, with its focus on the repression of traumatic memory; and survivor writings, which explore the notion that the extremes of experiences are inaccessible because those who suffered the most are no longer with us. (5)

For Norridge, trauma theory, with its leaning towards deconstruction and psychoanalysis on the one hand, and Elaine Scarry's claim that pain destroys language on the other hand, have the tendency to homogenize the sufferings of colonized societies as universal suffering, the implication of which is denying the subjectivity inscribed in individual stories of pain (7-8). Caruth's notion of trauma, Felman and Laub's emphasis on testimony, and Norridge's idea of pain can enlighten an analysis of Kaine Agary's Yellow-Yellow. For instance, Caruth's theory of trauma, contingent upon unavailability of knowledge about the event, is to a large extent valid on the grounds that narratives and testimonies about traumatic events are usually constructed through memory after a particular event has been lost in time and space. This proposition suggests that testimonies are vulnerable to vagaries of the survivor's memory, which is usually elliptical precisely because it is necessarily selective. Some scholars have emphasized the problem of memory in the testimonies of survivors, particularly the way in which traumatic events destabilize memory (Krystal, et al. 157; Herman 5; Loftus, et al. 66). Felman and Laub also state that, regardless of distortion of memory, telling one's story is necessary for one's survival (78).

Meanwhile, Norridge is sensitive to the power relations that govern the hierarchy of stories, a hierarchy in which the stories of minorities are silenced in the broader discourse of pain as universal experience, through the obliteration of difference. While conscious of the gaps in testimonies of trauma survivors, it is important to acknowledge that all narratives are elliptical. Likewise, rather than homogenizing the stories of minorities as 
universal testimony of pain, Norridge resists the notion of the "unspeakable" stories and creates the possibility of empowering the narratives from the periphery of dominant narratives. In other words, while being aware of the limitations of traumatic stories, the survivors nevertheless must retain their narrative agency no matter how elliptical they may be.

Yellow-Yellow begins with the violent displacement of the protagonist's mother from her farmland as a result of oil spillage, signaling one of the prevalent environmental challenges that beleaguers the Niger-Delta. Afterwards, Zilayefa (the protagonist) describes the claustrophobic atmosphere of her village and expresses her desire to escape to Port Harcourt. Her desperation to leave the village brings her in contact with a Spaniard, Sergio, who visits the village to attend the funeral ceremony organized by one of the wealthiest families. For Zilayefa, Sergio is her lifeline out of the village drudgery, and she is dismayed when he disappears. Zilayefa eventually finds a job in Port Harcourt, where she is impregnated by an older predatory man named Admiral Kenneth Alowei Amalayefa. Meanwhile, Zilayefa later re-crosses paths with Sergio and has a sexual encounter with him. Because she is unsure of who is responsible for the pregnancy, she decides to get rid of it. The anguish of the abortion and the relief it brings her can be read as being parallel to the dictatorship and the death of the Nigerian tyrant Sani Abacha. Therefore, the novel ends on the note of a new beginning, both for Zilayefa and Nigeria.

\section{Racial authenticity}

One major experience that shapes Zilayefa's outlook on life generally and the lives of biracial women in particular is her encounter with the metanarrative of racial authenticity rendered by another biracial woman named Sisi. This experience emerges from Sisi's story which emphasizes society's expectations of racial purity and its agonizing effects on biracial children who apparently defy the white/black binary. In her story, Sisi tells Zilayefa that her potential father-in-law prevented his son from marrying her because her father was a European (101). When Sisi says, "Because my papa na oyinbo. His son had to marry someone whose lineage he knew" (101), there is the temptation to conclude that Sisi's would-be father-in-law opposed the marriage because of her European paternity. Therefore, when Sisi explains that "His son had to marry someone whose lineage he knew", she implies that the father-in-law was unable to see her exclusively as either white or black. This discourse resonates with perceptions of biracial people as unnatural and degenerate. Laura Ann Stoler argues that, within the contexts of British, French, and Dutch colonial projects, "[d]egeneration was defined as "departures from the normal human type [...] transmitted through inheritance and lead[ing] progressively to destruction"' (62). Degeneracy was also believed to have social and political consequences. Stoller states, "Through sexual contact with native women, European men 'contracted' disease as well as debased sentiments, immoral proclivities, and extreme susceptibility to uncivilized states" (67-8). Whiteness may have dominated the colonial situation, but it is blackness that assumes superiority in the postcolonial context of Agary's Yellow-Yellow. Meanwhile, through her discussion with Sisi, Zilayefa now understands that "knowing my father would not release me from society's judgment" (101). Consequently, since Sisi's and Zilayefa's bodies do not fit into the binary codes of the races, they are pushed to the periphery of racial signification.

The exclusion also operates through the simultaneous visibility and invisibility imposed on biracial bodies. Sisi's identity is denied and is regarded as 'other'. In this way, she is made invisible. However, more insidious working of the discourse of racial authenticity is ironically the visibility accorded the biracial body through valorization of the light skin. Once Zilayefa has been accepted as one of the staff in a hotel in Port Harcourt, her supervisor Mr. Moses announces, "Dem don send us anoder mami-wata o" (They have sent us another Mammy water) (71). Even though the phrase "Mammy water" is used mostly in the Niger-Delta region of Nigeria to address any woman who is beautiful and who possesses a very light complexion, its reference becomes more powerful when applied to biracial women. Along with Mammy water come stereotypes, one of which is deadly hyper-sexuality. So, while Nigerian society valorizes the beauty of biracial women, it does so by regarding their beauty and purported hyper-sexuality as destructive. The problem with the stereotype of the Mammy water is that it mythologizes biracial women and deprives them of human value. Also, such women are stigmatized as morally weak. Zilayefa's understanding of these social prejudices is expressed as follows: "I came to understand that people had preconceived notions about others of mixed race-they thought we were conceited, promiscuous, undisciplined, and confused. A mixed-race woman in a position of power must have gotten there because of her looks [...] We were products of women [...] who did not have morals to pass on to their children" (74; original emphasis). Valorizing the light skin of mixed-race women on the one hand may signify physical attraction but it is also 
coded with fear of unrestrained sexuality that often makes them vulnerable to male sexual exploitation. For instance, Zilayefa later realizes that Admiral has been exploiting her. By stating that "Those promises of 'I will take care of whatever you need' were falling on the ears of another pretty girl" (173), Zilayefa understands that Admiral is interested only in his sexual gratification.

Consequently, biracial women such as Sisi and Zilayefa are targets of reckless male sexual desire. Zilayefa's biracial friend and colleague, Emem, is aware of these stereotypes and has developed her coping strategies. In the first place, she understands that the stereotypes do not entirely define her subjectivity. Also, she undermines the power and authority of the stereotypes by reclaiming them. In other words, Emem self-consciously plays the role of the 'other' by fulfilling men's sexual desire for material profit. This way, she elevates herself from the position of victim to that of subject. Zilayefa says of her: "Emem never seemed to lack for anything [...] [S] he took care of her family and even made up tear-inducing stories in their name to get money from her male admirers" (128). Although most of the critical responses to Yellow-Yellow represent prostitution as a social vice that suggests women's powerlessness (Simon 157; Feghabo 322; Janis 326), the text appropriates the stereotype of prostitution towards the agency of biracial women.

As the novel demonstrates, the dialectic of visibility and invisibility leads to the hysterization of the female body (see Foucault 103-5). The biracial body becomes the "sexual body" par excellence. For example, Zilayefa says Emem has a "string of men who want to date her" (128), and also says of herself: "Attention from men was not a new thing to me [...] There were men of all shapes" (71). This hysterization of the biracial body can also be seen when the protagonist reports that village girls bleach their skin to achieve greater sexual appeal for their sex trade in the cities. For these girls, the biracial skin appears to be the most desirable, a point that Zilayefa seems to corroborate when she states that "Some of them would even compare their new complexions to mine, saying how they were almost as yellow as I was" (36). Regardless of this instrumentation of the yellow skin by village sex workers, the fact that biracial bodies are seen almost exclusively as sexual bodies has a painful impact on Zilayefa who discovers that biracial women are stereotyped as hyper-sexual and, at the same time, are expected to serve as disposable tools for the fulfillment of male (hetero)sexual fantasy. It is necessary, therefore, to explore the ways in which this novel constructs its discourse of trauma and shows its impact on mixed-race women, particularly the protagonist, Zilayefa.

\section{Biracialism and trauma}

One thing that qualifies Yellow-Yellow as a trauma narrative is the effacement of the primal scene from the text. Ina Binaebi, Zilayefa's Ijaw mother, is the primary witness to her father's vanishing act. Right from its opening pages the novel foreshadows Zilayefa's imbrications in her mother's traumatic experience by highlighting the two women's resemblance. She emphasizes this fact when she says, "aside from my complexion, I looked like her, right down to the little birthmark below her left eye" (20). Zilayefa is the younger Binaebi: "When I looked at her, I saw a petite woman with an oval face, big dreamy eyes, a nose that looked like God was running low on clay the day he made it, and small lips that parted to reveal a charming gap-toothed smile. People often said to me, 'Your mother just went and gave birth to her twin"' (20). The similarity between the two women goes beyond mere physical or biological affinities; the adventurous journey to the city of Port Harcourt, the high expectations for success, the pursuit of love with an expatriate, the pregnancy, and the disappointment that follows, all foreshadow a vicious cycle.

Sergio's appearance into the story marks Zilayefa's entry into the domain of trauma: "I didn't care for him one way or another, but seeing this man [Sergio] brought me thoughts of my father" (19). In fact, the attempt to deny the pain of her father's absence ironically attests to Zilayefa's unconscious repression of the anguish of her father's absence. This suggests a "compulsion to repeat", which implies that the subject "repeats exactly what it does not remember or what it would rather not remember mainly because it wants to avoid bringing it to consciousness" (Freud qtd in Burgin 293). Despite her denial of its significance to her life, ironically, Zilayefa simply confirms the operation of the past in her life. Her father's absence will later haunt her when she relocates to Port Harcourt, where she exhibits behaviors more symptomatic of trauma survivors. For instance, Zilayefa's desire to meet her father resurfaces when she encounters Romeo the sailor in Port Harcourt: "I wished I could ask him about my father. [...] She [her mother] skillfully avoided the subject when I brought it up [...] but with Romeo's stories, my craving for information about Plato resurfaced. My mother's total devotion to me had succeeded only in suppressing, not erasing, my desires to know about my other half" (108). Although she admits that her mixed-race identity 
was not an important subject in the village (74), the repressed past breaks through her mother's protective barrier in Port Harcourt.

Zilayefa's life in Port Harcourt epitomizes what Caruth calls traumatic returns, which is, the repeated rupture of a survivor's daily living by the repetition of a traumatic event either through memory or reliving the event (4). In no other act is this experience more emphatic than in Zilayefa's attraction to Admiral Amalayefa. It should be no surprise when she declares, "If I had the luxury of creating a dream father, he would definitely have come out looking like Admiral" (Yellow 120). More important, she explains that "I felt a deep sense of longing for him, not because of the comfort Emem hinted at, which was money, but because I was hoping that the relationship would give me a close paternal affection that I had never had" (138). Her first sexual encounter is motivated by the repetitive need and the recurrent desire for fatherly love, which she hopes to obtain from Admiral even if the price she has to pay is sex. More so, Admiral's over-indulgent attitude to her daughter, Alaere, only intensifies Zilayefa's pain of her father's absence and her attraction to Admiral. Both Admiral and Zilayefa are at cross purposes: the Admiral wants her for opportunistic sexual adventure while she wants him for a fatherly emotional bond (149).

Zilayefa is quite ambivalent about the sexual aspect of her relationship to Admiral because she constantly remembers her mother's admonition not to "spoil" herself. However, the prospects of obtaining fatherly love seem stronger than her resistance to sex. Therefore, she recuperates her father's memory in other men, which according to Caruth, only affirms the repetitive return to the primal scene of the father's disappearance. So when she says, "I found myself drawn to Admiral like a fly to a gourd of palm wine. I like the fact that, even though the first thing on his mind might have been getting me into bed [...] I wanted him to dote on me as I had seen him dote on Alaere" (139-40), Zilayefa simply confirms her desire for a father and, if there is any exchange between the two of them at all, it is offering her body to Admiral in return for emotional safety and support she had seen Admiral lavish on her daughter Alaere (145).

Meanwhile, the story takes a different turn once Zilayefa becomes pregnant, mainly because she realizes that her story seems like a repetition of her mother's tale. On the one hand, Admiral's almost exclusively predatory sexual interest no longer provides the anticipated fatherly security and reassurance. Zilayefa says, "I was jolted into reality. Admiral did not have the time to commit to me [...] I expected that a man his age, with his comforts, would welcome the news of fathering a child. But I should have known better, and I had no one to blame but myself since his reputation with young girls far, far, preceded him" (162). On the other, she is terrified of bearing another child who might have to endure the stigma of biracialism in case Sergio is responsible. This climactic point in the novel marks Zilayefa's admission of the pain that she has tried so much to smother. She exemplifies Shoshana Felman and Dori Laub's argument in their discussion of the centrality of testimony to survival. According to them, victims of trauma not only survive to tell their stories, but also need to tell their stories to survive (78). Zilayefa recovers the story of biracial children from the public imagination where biracialism signifies otherness and stereotypes such as hyper-sexuality and racial ambiguity. Although this moment functions as the culmination of the story, it has its roots much earlier in the novel. In order to appreciate the ways in which Zilayefa possesses her story, it is necessary to explore how the text foregrounds and privileges the voice of the 'other'. It is a strategy to reclaim subjectivity, which seems virtually unattainable without a counter-narrative that challenges the grand narrative of racial difference.

\section{Testimony, subjectivity, and survival}

Zilayefa's account of her pain does not follow the structure of most testimonies. Felman and Laub explain that "The testimony to the trauma thus includes its hearer, who is, so to speak, the blank screen on which the event comes to be inscribed for the first time" (57). In Yellow-Yellow, there is no such listener to Zilayefa's narrative. However, the text nevertheless mimics testimony in that the victim speaks for the first time to readers who occupy the space of "hearers". More important, one object of testimony is to empower the victim to witness the past in order to undermine the tyranny of the past (Felman and Laub 79).

Therefore, as soon as the story shifts to Port Harcourt, it is clear that the novel offers narrative agency to Zilayefa. On her arrival at Sisi's office, Clara, one of Sisi's employees, provides Zilayefa with her employer's biography in such a detailed manner, chronicling her success, entrepreneurship, and kindness. However, despite the details, or precisely because of the details, Zilayefa could not help question Clara's story as follows:

Clara seemed like a nice person, but I could not help but wonder how much of what she had told me was true. Several times as she intimated the details of Sisi and Lolo's lives, I was surprised at how much she disclosed and wondered if she 
discussed these intimate details just as freely with everyone who came into the shop when Sisi was not around. She had given me a lot of information, which I appreciated but did not know what to do with. It was more than I needed, but I did not tell her to stop. On my part, I enjoyed her melodrama as she acquainted me with the two strangers who would become my family, my lifeline, in Port Harcourt. There was no hearsay with her-she narrated with the authority of one who was always present. (60)

This self-reflexive moment connects Sisi and Zilayefa and establishes stigmatization and stereotypes as shared experiences. Clara's story, when juxtaposed with Sisi's own account of her life, is incomparable to the latter's in that while Zilayefa simply marvels at the details and authority of Clara's story, she discovers that her life parallels Sisi's: "I listened to Sisi, slowly appreciating the fact that knowing my father would not release me from society's judgment. At that moment, the realization was comforting" (101). Despite the manifold information provided through Clara's voice, the pain of living in a society prejudiced against biracial people becomes bearable. In contrast, Sisi's story helps Zilayefa to open up about her pain as a biracial young woman.

Therefore, when Sisi claims narrative agency like Zilayefa and Emem, their account displaces Clara's version. Certainly, Clara does not necessarily portray Sisi in a derogatory manner, but the novel privileges witnessing to one's own pain. Yellow-Yellow shows that rendering one's own testimony empowers the victim by undermining the terror of the past that inheres in silence. Zilayefa may not have achieved closure, but being able to connect with other victims may serve as a catalyst to healing. For instance, sensing Zilayefa's anxiety, Emem counsels her to ignore stereotypes and judgmental voices of society: "It did not matter what people thought of me because of my complexion" (75). Of course, it matters what other people thought of Zilayefa, Sisi, and Emem because of their complexion because such thoughts make the victims relive their pain. However, the important thing is that relocating narrative agency to the victims becomes the first step towards recreating biracial subjectivity in the novel.

Empowered by her voice, the protagonist confronts the demons from her past for the first time. Towards the end of the novel, Zilayefa expresses her anxiety and pain about exclusion and stigmatization as social outcast and sexual fetish. Zilayefa says, "Maybe when Emem and I shared a private joke, people around us understood that we were just being normal, ticklish young girls and not brats with the conceited sensibilities of which they accused mixed-race people" (75). Despite the magnitude of social prejudice and feeling of estrangement, the opportunity to tell her story helps Zilayefa to confront and transgress the grand narrative of racial purity.

The visibility of biracial children and racial slurs that come with it such as "African profits", "born-troways", "ashawopickins", and "father-unknowns" (171), help Zilayefa to express her frustration with her dual heritage. She therefore describes the extent to which she has been interpellated and caught up in the negativity adduced to mixed-race children by admitting that "I had the blood of a foreigner running through my veins and his genes confronting me every time I look at myself" (75). Therefore, when she encounters Sergio again in Port Harcourt, she cannot help wondering why young twenty-year old girls find their white spouses irresistible. Her inability to comprehend inter-racial love forces her to invisibility: "Maybe then [when she understands the attraction of inter-racial romance] I would not hide from the facts of my birth that my yellow skin and curly hair put on display" (171). The visibility of mixed-race women paradoxically forces them into a state of double effacement, first by social exclusion and second by self-effacement.

In order to demonstrate the uniqueness of her experience, the novel makes a distinction between biracial children and children of endogamous relationships whose fathers are no longer present. Comparing the latter to herself she says, "[T] heir secrets were not revealed in their complexion or the waves in their hair; mine was" (174). Even though this testimony does not automatically signify complete relief of her suffering, it empowers her to reconstruct her subjectivity. For instance, the abortion that ends the story, and which coincides with the death of Nigeria's dictator, Sani Abacha, shows Zilayefa's ability to reach into her inner will-power to initiate a new story. Just as Nigeria begins a new life after the demise of the dictator, Zilayefa also begins to advance towards a future that is uniquely hers.

\section{Conclusion}

Kaine Agary's Yellow-Yellow illustrates a hierarchy of discourses in which racial chauvinism, that is, the essentialist and normative approach to blackness, effaces and silences the voices of biracial people. Therefore, Agary's novel shows that the marginality of biracial people ironically objectifies them not only as objects of male sexual fantasy, but also as easy, inconsequential, and disposable apparatuses of gratuitous male libido. However, the novel also 
demonstrates that this traumatic experience is a gendered one, especially because women seem more vulnerable to sexual exploitation than men. Rather than antagonizing this discriminatory discourse and essentializing biracial identity, Yellow-Yellow questions the normativity of blackness by foregrounding its logic of exclusion, emphasizes the psychic suffering it imposes on its victims, and empowers victims through their testimonies. Zilayefa's narration of her anxiety, pain, and trauma serves a specific purpose, which is to humanize her as well as to produce her story that functions as counter-narrative to the repressive fallacy of racial supremacy, whether black or white.

\section{Acknowledgement}

The author gratefully acknowledges research funding awarded by the German Academic Exchange Service (DAAD) in July and August 2017.

Notes

1. The term 'half-caste' is often used colloquially in Nigeria. Though 'biracial' is not unproblematic (since race is a construct), the term is used here for lack of a viable alternative.

\section{Works Cited}

Agary, Kaine. Yellow-Yellow. Dtalkshop, 2006

Azumurana, Solomon O. 'Freud's 'Penis Envy,' Lacan's the 'Desire to be the Other' Nigerian Feminist Aesthetics: AdimoraEzeigbo's Children of the Eagle and Kaine Agary's Yellow-Yellow." Journal of the African Literature Association vol. 6, no. 1, 2016, pp. 151-63. DOI: https://doi.org/10.1080/21674736.2011.11690177.

Burgin, Victor. In/Different Spaces: Places and Memory in Visual Culture. U of California P, 1996.

Caruth, Cathy. Unclaimed Experience: Trauma, Narrative, and History. Johns Hopkins U P, 1996.

Chukwumah, Ignatius. "The Displaced Male-Image in Kaine Agary's Yellow-Yellow." Tydskrif vir Letterkunde vol. 50, no. 2, 2013. pp. 47-62. DOI: http://dx.doi.org/10.4314/tvl.v50i2.4.

Feghabo, Charles Cliff. "Inverting Otherness in Kaine Agary's Yellow-Yellow." Matatu vol. 45, no, 1, 2014, pp. 315-32. DOI: https://doi.org/10.1163/9789401211093 019.

Felman, Shoshana \& Dori Laub. Testimony: Crisis of Witnessing in Literature, Psychoanalysis, and History. Routledge, 1992.

Foucault, Michel. The History of Sexuality: An Introduction. Trans. Robert Hurley. Vintage, 1978.

Herman, Judith L. "Crime and Memory." Trauma and Self. Eds. Charles B. Stozier \& Michael Flynn. Rowman \& Littlefield, 1995, pp. 3-17.

Janis, Michael. "Yellow-Yellow." Africa: Journal of the International African Institute vol. 78, no. 2, 2008, pp. 325-26. https://jstor.org/ stable/29734341.

Krystal, John H. et al. "Post Traumatic Stress Disorder: Psychological Mechanisms of Traumatic Remembrance." Memory Distortion: How Minds, Brains, and Societies Reconstruct the Past. Eds. Daniel E. Schacter. Harvard U P, 1995, pp. 150-72.

Loftus, Elizabeth F. et al. "The Reality of Illusory Memories." Memory Distortion: How Minds, Brains, and Societies Reconstruct the Past. Ed. Daniel E. Schacter. Harvard U P, 1995, pp. 47-68.

Norridge, Zoe. Perceiving Pain in African Literature. Palgrave Macmillan, 2013.

Simon, E. D. "The Niger Delta Region and the Woman's Predicament: A Study of Kaine Agary's Yellow-Yellow." African Research Review vol. 4, no. 3b, 2010, pp. 155-66.

Stoler, Laura Ann. Carnal Knowledge and Imperial Power: Race and the Intimate in Colonial Rule. U of California P, 2010. 